eases. Our academic and personal links with the US scientific community are stronger than ever in all aspects of infectious diseases, including nosocomial infection, prevention, and control. However, we need to develop more effective training programs for infection control nurses, infection control practitioners, and hospital epidemiologists, and we need to find ways to convince our administrators of the real benefits and costs of the infection control programs. ${ }^{9}$

\section{CONCLUSION}

We still have a long way to go before our nosocomial infection control and quality assurance systems ${ }^{10}$ will equal those existing in the United States, but with a lot of helping hands working together on both sides of the Atlantic, we continue to pursue excellence.

\section{REFERENCES}

1. Comisión de Análisis y Evaluación del Sistema Nacional de Salud. Informe de la Escuela; Nacional de Sanidad. Madrid, Spain; 1991.
2. Subdirección General de Prestaciones y Evaluación de Tecnologias Sanitarias (Ministerio de Sanidad y Consumo): Informe sobre Infección Hospitalaria. Med Clin (Barc) 1994; 102:20-24.

3. EPINE Working Group. Prevalence of hospital-acquired infections in Spain. J Hosp Infect 1992;20:1-13.

4. Vaqué J, ed. Prevalencia de las infecciones nosocomiales en los hospitales Españoles: EPINE 1990-1994. In: Sociedad Española de Higiene y Medicina Preventiva Hospitalarias; 1995; Madrid, Spain.

5. Trilla A, Wenzel RP. Infecciones por Staphylococcus aureus resistentes a la meticilina: un reto para el control de infecciones. Enferm Infecc Microbiol Clin 1991;9:193-195.

6. Trilla A, Miro JM. Control de la Infección Nosocomial: ¿quién?, ¿cómo? y ¿cuénto cuesta? Medicina Clinica 1989;92:217-219.

7. Wenzel RP, ed. Prevention and Control of Nosocomial Infections. 2nd ed. Baltimore, MD: Williams \& Wilkins; 1993.

8. Bennet JV, Brachmann PS, eds. Hospital Infections. 3rd ed. Boston, MA: Little Brown \& Co; 1992.

9. Vaqué J, Roselló J, Trilla A, et al. Nosocomial infections in Spain: results of five nationwide serial prevalence surveys (EPINE project, 1990-1994). Infect Control Hosp Epidemiol 1996;17:293-297.

10. Asenjo MA, Lledó R, Trilla A: Quality assesment in Spanish hospitals. Clin Perform Qual Health Care 1994;2:97-99.

\title{
9,000 E Coli Cases in Japan
}

\section{Gina Pugliese, RN, MS Martin S. Favero, $\mathrm{PhD}$ Medical News Editors}

Nearly 9,000 Japanese have been infected with Escherichia coli O157:H7 since May; seven people have died. The cases have occurred throughout Japan; the most serious outbreak was in Sakai, a city near Osaka where more than 6,000 elementary school children became ill, presumably from contaminated lunches. The number of new cases had slowed by early August: hospital- izations dropped to 440 , from a peak of 595 in late July, and the number of elementary school children in serious condition dropped to 17 from more than 90 .

By offering free screening, health officials have identified 284 infected but asymptomatic individuals. Japanese officials have been unable to find the source of most of the outbreaks. Officials reported that the organisms causing the outbreaks in seven of the affected areas were genetically similar, but different from the strain in Osaka. Experts on bacte- rial infections from the $\mathrm{CDC}$ are conferring with health authorities in Tokyo.

Japan's Health and Welfare Ministry has decided to designate the infection as a serious communicable disease under a century-old anti-epidemic law that gives the government the power to screen those at risk and to restrict infected food handlers from work.

FROM: Pollack A. Japan decides to use an old law on epidemics to combat food poisoning. New York Times August 1, 1996;A3. 